\title{
Qualitative Study on the Phytochemical Constituents of the Flower Buds of Bauhinia variegata
}

\author{
Kew KS ${ }^{1}$, Neivashini $M^{1}$, Ooi XC ${ }^{1}$, Perveen Nabila ${ }^{2}$ and Naeem Hasan Khan ${ }^{1 \star}$ \\ ${ }^{\prime}$ Faculty of Pharmacy, AIMST University, Bedong, Kedah D.A., Malaysia \\ ${ }^{2}$ School of Pharmaceutical Sciences, Universiti Sains Malaysia (U.S.M.), Penang, Malaysia
}

\section{Article Info}

\author{
*Corresponding author: \\ Naeem Hasan Khan \\ Professor \\ Faculty of Pharmacy \\ AIMST University \\ Bedong, Kedah D.A \\ Malaysia \\ Tel: 006016 9372470, 00604429 8000/ext. 1280 \\ E-mail: naeemhshirazi@hotmail.com
}

Received: January 29, 2018

Accepted: May 22, 2018

Published: May 28, 2018

Citation: Kew KS, Neivashini M, Ooi XC, Nabila P, Khan NH. Qualitative study on the Phytochemical Constituents of the flower buds of Bauhinia variegata. Madridge J Pharm Res. 2018; 2(1): 47-51.

doi: $10.18689 / \mathrm{mjpr}-1000108$

Copyright: (c) 2018 The Author(s). This work is licensed under a Creative Commons Attribution 4.0 International License, which permits unrestricted use, distribution, and reproduction in any medium, provided the original work is properly cited.

Published by Madridge Publishers

\begin{abstract}
The objective of the present study was to do qualitative evaluation of phytochemicals present in the flower buds of Bauhinia variegata that belongs to a family "Fabaceae' which is well known for its scented flowers. The young premature flower buds of the plant were subjected to analysis for its phytochemical constituents as fresh material. The fresh raw flower buds of the plant were macerated and subjected to hot percolation separately. The maceration was carried out for 72 hours with absolute alcohol. The hot percolation (Soxhelt extraction) was carried out in intervals, approximately for 40 hours). The shade dried flower buds were also underwent for maceration and hot percolation separately with absolute alcohol. The extracts were dried over rotary evaporated. After evaporation, the greenish pinkish colour gummy mass was obtained from the fresh flower bud extractions. The evaporated extracts of shade dried flower buds were of greenish gummy mass. Some of the extracts were of greenish yellow and greenish in colour. All evaporated extracts were dissolved and diluted in respective solvents for phytochemical analysis. The qualitative screening of analytical results showed the presence of alkaloids, reducing sugars, terpenoids, glycosides, tannins, flavonoids and carbohydrates in all the extractions. The tests for saponins revealed that this group was not present in any of the solvent extracts. Anthraquinones showed the presence in Flower A and Bud SA only while this group was not present in Flower B, Bud A and Bud B samples.
\end{abstract}

Keywords: Bauhinia variegata; Maceration; Hot percolation; Phyto-chemical constituents; Qualitative analysis.

\section{Introduction}

Bauhinia variegata is a species of a flowering plant belonging to the family 'Fabaceae', which is native to Southeast Asia, Southern China, Pakistan and India. Common names Bauhinia variegata includes asorchid tree, mountain ebony, kachnar (in Indian Sub-Continent). Other vernacular names are: Bauhinia, Bois de Boeuf, Camel's foot, Palo di Orqu, Pata di Rez, Poor man's orchid, Sabot boeuf, St. Thomas tree, variegata bauhinia [1]. This is a popular ornamental tree in sub-tropical and tropical climate which is grown for its scented flowers at altitude between 100-650 M (300-2000 ft.) [1]. Due to high levels of exploitation and habitat loss, large trees are scarce and tree is listed as an endangered species [1]. In the neotropic regions, Bauhinia variegata tree issued to attract humming birds as 'Sapphire-spangled Emerald (Amazilialactea) and Glitteringbellied Emarald (Leucochrisalbicollis) in the gardens and parks [1]. Bauhinia variegata beautifully blooms for several months from March to Mid-May [2]. 
Bauhinia variegata grows $20-35 \mathrm{ft}$. tall and 20-30 ft. wide with spreading crown of deciduous leaves which are 4-6 inches $(10-15 \mathrm{~cm})$ across and rounded with lobed ands and heart shape bases, thin leathery, simple but deeply cleft at apex, forming two rounded lobes, lower surfaces downy at the top of petioles. The flowers often make their appearance in late winter while the blooming period lasts until early summer. The fruit is a pod $15-30 \mathrm{~cm}$ long containing several seeds [2]. The blossom is spectacular and the tree is covered with flowers looking like orchids. The flowers are followed by pods, maturing rapidly [3]. The chemical constituents isolated so far from the plant are $\beta$-sitosterol, kaempferol-3-glucoside, tannins, carbohydrates, amides, reducing sugars, vitamin, crude protein, fibers, calcium phosphate, apigenin-7-oglucoside, hepatatriacontan-12-13-diol and dotetracontan 15-el-9-ol, extracted from dried leaves 'Bauhinia variegata' by petroleum ether for the first time [4-6]. The phyto-constituents with different solvents from the leaves of Bauhinia variegata contains tannins, alkaloids, steroids, cardiac glycosides, anthraquinones, saponins, flavonoids, coumarin and sugars variably [6].

Fine-grained wood of Bauhinia variegata is highly valuable and used for many purposes including high quality furniture, decoration for house construction, musical instruments and carving. Bark is used for tanning hides, young seeds, leaves, flowers and fruits are edible and eaten as vegetable or pickle, tree is nitrogen fixing and is prized throughout Asia [7-8].

Almost all the parts of the tree Bauhinia variegata are used pharmacologically as in obesity, bleeding piles, worms, cough, inflammatory skin diseases, balancing activity of thyroxin production, haematuria, dysuria, anti-ulcer, menorrhagia and goitre and many others [9]. Ethanolic extract of the bark of Bauhinia variegata is an anticancer to human epidermal carcinoma of the naso-pharynx [10-11]. The aim and objective of the present study was to carry out qualitative screening of phytochemical constituents of the shade dried fresh flower buds.

\section{Materials and methods}

\section{Plant material}

Few of the Bauhinia variegata trees (6 trees) were spotted in Universiti Sains Malaysia (U.S.M.), Penang near the old building of 'Subaida Restourant'. The young flower buds (yet folded and not bloomed) of Bauhinia variegata were plucked from the tree. About $3.5 \mathrm{~kg}$ of the raw material was collected. Flower buds (premature yet folded and not bloomed) were immediately transported to place of analysis. In the laboratory, raw material was gently washed manually with tap water and then rinsed thoroughly with distilled water. Wrapped with plastic foil and put in the refrigerator at about $6^{\circ} \mathrm{C}$.

\section{Chemicals}

Absolute alcohol was (95\% chem. Pure, molecular weight $46.07 \mathrm{~g} / \mathrm{mol}$ ) from HmbG, Germany. Water was freshly double-distilled in glass apparatus (Genristo, Nottingham, U.K.) in the laboratory.

\section{Instruments}

Blender, (model HGBPBKS6 240volts, AC50-60 Hz, 3.73 amps. Malaysia). Rotary evaporator (RE 300), Yamato, Japan Freeze dryer (Heto Super Modulyo), Digital analytic electronic balance (Mettler), Australia. Soxhlet apparatus (capacity 2L) Rest of all the glass apparatus and disposables were of high quality purchased from the local market. These instruments are purchased by the Central Laboratory Unit of AIMST University.

\section{Methodology}

\section{Maceration}

Maceration is one of the most frequently used technique in the extraction of essential oils and is also considered economical as well maceration makes use of the solvent which has the power to dissolve the aromatic compounds. The most common solvents used for this process are hexane, ethanol and dimethyl ether [12]. At the end of the process, the mixture is filtered to eliminate all the impurities and concentrated as necessary [13-14].

\section{With absolute alcohol}

Part1. About $300 \mathrm{~g}$ of fresh raw material (green buds not yet opened) was placed in $1 \mathrm{~L}$ capacity flat bottom flask and added to it $500 \mathrm{ml}$ of absolute alcohol till the raw material was fully soaked in the solvent. It was labelled as 'Bud A'. The flask was kept in the dark for five days with intermittent shaking the flask. Then it was filtered using water pump and subjected to vacuum rotary evaporator for concentration. The material recovered was $100 \mathrm{ml}$ as gummy semi solid. In other experiment as part 2, about $300 \mathrm{gm}$. of fresh raw flowers (pinkish red) were placed as such in $1 \mathrm{~L}$ capacity flat bottom flask and $500 \mathrm{ml}$ of absolute alcohol. Rest of the procedure was carried out as mentioned above. After evaporation, the material obtained was $100 \mathrm{~g}$ in gummy solid mask. It was marked as 'Flower $\mathbf{A}^{\text {'. }}$.

\section{With fresh double distilled water}

Part 1. About $300 \mathrm{~g}$ of fresh raw material (green buds not yet opened) was placed as such in $1 \mathrm{~L}$ capacity flat bottom flask and $500 \mathrm{ml}$ of fresh double distilled water. It was labelled as 'Bud B'. Rest of the process was carried out as stated above for the extraction with absolute alcohol. Material obtained was $90 \mathrm{~g}$ in the form of gummy semi solid at the end. As the second part of this extraction, $300 \mathrm{~g}$ of fresh raw flowers (pinkish red) were taken and rest of the process was adopted as stated above. It was labelled as 'Flower B'. The final material obtained was $90 \mathrm{~g}$ in the form of semi solid gummy mass.

\section{Hot percolation (Soxhlet extraction)}

It is considered the best technique where the continuous heating process is involved without the loss of substantial solvent. Soxhlet has been the technique used since a long and it is the main reference to which the performance of other leaching methods is compared. After final processing, the filtration and concentration is done as required [15-16]. 


\section{With absolute alcohol}

Shade dried raw material (green buds not yet opened) was crushed to course powder. $300 \mathrm{~g}$ of this crushed material was packed in thimble and added with $500 \mathrm{ml}$ of absolute alcohol into it till the raw material was fully soaked in the solvent. The temperature was kept constant at $60^{\circ} \mathrm{C}$. It was labelled as 'Bud SA'. The hot percolation was carried out for about 48 hours till the extraction becomes clear in the thimble. Then the percolate was filtered and finally subjected to vacuum rotary evaporator for concentration. The total mass obtained afterwards was $85 \mathrm{gm}$. The finally recovered material was $100 \mathrm{~g}$ in semi solid form. The detail for the laboratory coding of all the extracts is shown in table 1. The different colours of mass of the final products are shown in table 2.

Table 1. Coding of the different extracts of Bauhinia variegata

\begin{tabular}{|l|l|l|}
\hline $\begin{array}{l}\text { No. of } \\
\text { extract }\end{array}$ & Process of extract & $\begin{array}{l}\text { Laboratory codes of } \\
\text { Extract }\end{array}$ \\
\hline 1. & Maceration with absolute alcohol & Bud A (A1) \\
\hline 2. & Maceration with absolute alcohol & Flower A (A2) \\
\hline 3. & Maceration with double distilled water & Bud B (B1) \\
\hline 4. & Maceration with double distilled water & Flower B (B2) \\
\hline 5. & $\begin{array}{l}\text { Hot percolation with absolute alcohol } \\
\text { (Soxhlet extraction) }\end{array}$ & Bud SA (SA1) \\
\hline
\end{tabular}

Table 2. Recovery of the different extracts of Bauhinia variegata after final processing

\begin{tabular}{|l|l|l|l|l|l|}
\hline No. & $\begin{array}{l}\text { Laboratory } \\
\text { code of } \\
\text { extract }\end{array}$ & $\begin{array}{l}\text { Mass of } \\
\text { starting } \\
\text { material }\end{array}$ & $\begin{array}{l}\text { Recovery of } \\
\text { evaporated mass } \\
\text { (yield) }\end{array}$ & $\begin{array}{l}\text { Colour of } \\
\text { the final } \\
\text { product }\end{array}$ & $\begin{array}{l}\text { Recovery of } \\
\text { evaporated } \\
\text { mass } \\
\text { (\%) }\end{array}$ \\
\hline 1. & Bud A (A1) & $300 \mathrm{~g}$ & $\begin{array}{l}100 \mathrm{~g} \text { gummy semi } \\
\text { solid }\end{array}$ & $\begin{array}{l}\text { Greenish } \\
\text { yellow }\end{array}$ & 33.3 \\
\hline 2. & Flower A (A2) & $300 \mathrm{~g}$ & $\begin{array}{l}100 \mathrm{~g} \text { gummy solid } \\
\text { mass }\end{array}$ & $\begin{array}{l}\text { Greenish } \\
\text { pink }\end{array}$ & 33.3 \\
\hline 3. & Bud B (B1) & $300 \mathrm{~g}$ & $\begin{array}{l}90 \mathrm{~g} \\
\text { gummy semi solid }\end{array}$ & $\begin{array}{l}\text { Greenish } \\
\text { yellow }\end{array}$ & 30.0 \\
\hline 4. & Flower B (B2) & $300 \mathrm{~g}$ & $\begin{array}{l}90 \mathrm{~g} \\
\text { gummy semi solid }\end{array}$ & $\begin{array}{l}\text { Greenish } \\
\text { yellow }\end{array}$ & 30.0 \\
\hline 5. & Bud SA (SA1) & $300 \mathrm{~g}$ & $\begin{array}{l}85 \mathrm{~g} \\
\text { semi solid mass }\end{array}$ & Greenish & 28.3 \\
\hline
\end{tabular}

The percentage yield of Bud $A(A 1)$ and Flower $A(A 2)$ was $33.3 \%$ (100 g). After maceration with absolute alcohol, the percentage yield of Bud B (B1) and Flower B (B2) was 30\% $(100 \mathrm{~g})$. The final yield with double distilled water was $85 \mathrm{~g}$ (28.3\%). The results showed the highest percentage yield was obtained by maceration with absolute alcohol.

\section{Dilution of extracts for qualitative analysis}

The evaporated extracts were very deep and dense in colours, so, the dilution was carried out for analysis of phytochemical constituents. The laboratory coded extracts $\mathrm{A} 1, \mathrm{~A} 2$ and SA1 were diluted as 0.5:50 (0.5 g of respective extract with $50 \mathrm{ml}$ of absolute ethanol), separately. The laboratory coded extracts B1 and B2 were diluted as 0.25:50 ( $0.25 \mathrm{~g}$ of respective extract with $50 \mathrm{ml}$ of absolute ethanol), separately.

\section{Tests for qualitative analysis of phytochemical constituents $[17,18]$}

All the tests were performed on above mentioned extracts separately and repeated for three to four times, as necessary.
Test for alkaloids: $1.0 \mathrm{ml}$ of each extract was warmed with $2.0 \mathrm{ml}$ of $2 \%$ sulphuric acid for two minutes, filtered and then added a few drops of 'Dragendorff's reagent'.

Test for reducing sugars: $1.0 \mathrm{ml}$ of each extract was shaken with $1 \mathrm{ml}$ of distilled water and filtered. Filtrate then was boiled with a few drops of 'Fehling solution $A$ and $B$ '(equal volume of Fehling $A$ and $B$ ) and kept for about five minutes.

Test for saponins: $1.0 \mathrm{ml}$ of each extract was added with $5 \mathrm{ml}$ of distilled water, boiled and kept for cooling.

Test for terpenoids: $1.0 \mathrm{ml}$ of each extract was mixed with 2 $\mathrm{ml}$ of chloroform and then $3 \mathrm{ml}$ of sulphuric acid was added gently to form a layer. It is called 'Salkowski test'.

Test for anthraquinones: $1.0 \mathrm{ml}$ of each extract was boiled with $2 \mathrm{ml}$ of $10 \%$ of hydrochloric acid solution for a few minutes in a water bath. Filtered and cooled. Filtrate was added with equal volume of chloroform and finally $10 \%$ of ammonia solution was added to the mixture.

Test for glycosides: $1.0 \mathrm{ml}$ of each extract was hydrolysed with $1 \mathrm{ml}$ of $10 \%$ of hydrochloric acid solution and neutralized with $1 \mathrm{ml}$ of $0.2 \mathrm{M}$ of sodium hydroxide solution. Finally a few drops of Fehling's solution mixture ( $A$ and $B$ already mixed) were added in the mixture.

Test for tannins: $1.0 \mathrm{ml}$ of each extract was mixed with $2 \mathrm{ml}$ of distilled water and heated over water bath, cooled and filtered. To $1 \mathrm{ml}$ of this filtrate, $1 \mathrm{ml}$ of ferric chloride was added.

Test for flavonoids: $1.0 \mathrm{ml}$ of each extract was dissolved in 1 $\mathrm{ml}$ of $2.0 \mathrm{M}$ sodium hydroxide solution and then $1 \mathrm{ml}$ of $10 \%$ hydrochloric acid solution was added.

Test for carbohydrates: $1.0 \mathrm{ml}$ of each extract was added with $0.2 \mathrm{ml}$ of Molische's reagent in a small test tube. Test tube was tilted at the angle of 45 then carefully and gently added $0.5 \mathrm{ml}$ of concentrated sulphuric acid alongside of the inner wall of the test tube.

\section{Results}

Most of the qualitative tests were positive in this study. For alkaloidal test, the green red precipitates were produced with Dragendroff's reagent. The alkaloids showed the presence in all the final extracts. The Dragendroff's reagent is a solution of potassium iodo-bismuthate $\left(\mathrm{KBil}_{4}\right)$. The acid reaction occurs when methyl red changes to orange or red colour at $\mathrm{pH} 7.1$ [19]. The reducing sugars were positive in all the extracts as well. Orange red precipitates were obtained after the addition of Fehling reagent that showed the presence of reducing sugars. Fehling solution A consists of hydrated copper (II) sulphate dissolved in $100 \mathrm{ml}$ of distilled water and Fehling $B$ contained $35 \mathrm{~g}$ of potassium sodium tartrate and $10 \mathrm{~g}$ of sodium hydroxide in $100 \mathrm{ml}$ of distilled water. Reducing sugars are easily oxidized to carboxylic acid and cupric ion is reduced to cuprous oxide [20]. The saponins have strong frothering power. There was appearance of creamy mass of small bubbles. The saponins were absent in all the extracts [20]. 
Terpenoid group was found to be present in all the extracts. For identification of anthraquinones, a rose pink colour was observed after the test that showed the presence of anthraquinones. The anthraqinones were not present in the samples of $A 1, A 2$ and $B 2$. This group was present in $B 2$ and SA1 samples. For the test of glycosides, the red precipitates were formed finally. All the samples showed the distinctly positive results for glycosides. The test for the presence of tannins showed presence in all the samples. Identification of tannins is based upon the principle of colouration produced by iron salts with ferric chloride. At the end, the dark green colour solution showed the presence of tannins.

Flavanoids were also positive in all the extracts giving yellow colouration at the end of qualitative test. Molisch's test was performed by using Molisch's reagent ( $\alpha$-naphthol in ethanol). The distinct red / purple / red-purple coloured ring formation showed the presence of carbohydrates [21]. The qualitative analytical results for the phytochemical constituents are tabulated in table 3.

Table 3. Phyto-chemical constituents with different solvent extracts from different parts of Bauhinia variegata

\begin{tabular}{|l|l|l|l|l|l|l|}
\hline No. & Chemical group & $\begin{array}{l}\text { Bud A } \\
\text { (A1) }\end{array}$ & $\begin{array}{l}\text { Flower A } \\
\text { (B2) }\end{array}$ & $\begin{array}{l}\text { Bud B } \\
\text { (A2) }\end{array}$ & $\begin{array}{l}\text { Flower B } \\
\text { (B2) }\end{array}$ & $\begin{array}{l}\text { Bud SA } \\
\text { (SA1) }\end{array}$ \\
\hline 1. & Alkaloids & + & + & + & + & + \\
\hline 2. & Reducing sugars & + & + & + & + & + \\
\hline 3. & Saponins & - & - & - & - & - \\
\hline 4. & Terpenoids & + & + & + & + & + \\
\hline 5. & Anthraquinones & - & + & - & - & + \\
\hline 6. & Glycosides & + & + & + & + & + \\
\hline 7. & Tannins & + & + & + & + & + \\
\hline 8. & Flavonoids & + & + & + & + & + \\
\hline 9. & Carbohydrates & + & + & + & + & + \\
\hline
\end{tabular}

$+=$ present,$-=$ absent

\section{Discussion}

The primary object of the present study was to carry out some of the important phytochemical analysis of Bauhinia variegata. The fresh buds (not yet bloomed) and the flowers of the plant were subjected to process of extraction by maceration and hot percolation using absolute alcohol and double distilled water. The macerated and hot percolation extracts were of different colours, specially dominated by the greenish colour. The maximum recovery of semi-solid gummy mass by maceration with absolute alcohol both in Bud $\mathrm{A}$ $33.3 \%$ and Flower $A$ was $33.3 \%$ respectively. It was observed that less semi-solid gummy extract was (28.3\%) collected after hot percolation with absolute alcohol in Bud SA. Similarly, about $30 \%$ of semi-solid mass was collected by maceration with double distilled water both in Bud B and Flower B. The results showed that saponins were not present in all the extracts. Furthermore, Bauhinia variegata fresh green buds (not yet bloomed) are tasty, costly vegetable with mild laxative activity. The fresh green buds (premature yet folded and not bloomed) are usually cooked with meat in the Province of Punjab Area of Indian Sub-Continent during the month of March and Mid-May [22].
This study showed that maximum percentage of gummy mass was obtained only by maceration with absolute alcohol, while minimum percentage of gummy mass was obtained by percolation with absolute alcohol. The qualitative phytochemical tests for alcohols, reducing sugars, terpenoids, glycosides, tannins, flavonoids and carbohydrates were positive in Bud $A$, Bud $B$ and Flower $B$. Anthraquinones group was present in Flower A and Bud SA only. The saponins were absent in all the analysed samples.

\section{Conflict of interest}

The authors declare that there is no conflict of interest.

\section{Single journal submission}

This original research paper has not been submitted anywhere else.

\section{Acknowledgement}

The present study is greatly acknowledged which was supported and financed by the Faculty of Pharmacy, AIMST University, Bedong, Kedah Darul Aman, Malaysia.

\section{References}

1. Parekh J, Karathia N, Chanda S. Evaluation of antibacterial activity and phytochemical analysis of Bauhinia variegata L. bark. African J Biomed Res. 2007; 10: 175-181.

2. Fang EF, Wong JH, Bah CS, Lin P, Tsao SW, Ng TB. Bauhinia variegata var. variegata trypsin inhibitor: from isolation to potential medicinal applications. Biochem Biophys Res Commun. 2010; 396(4): 806-811.

3. Yatish KV, Lalithamba HS, Suresh R, Harsha Hebbar HR. Optimization of Bauhinia variegata biodiesel production and its performance, combustion and emission study on diesel engine. Renewable Energy. 2018; 122: 561575. doi: 10.1016/j.renene.2018.01.124

4. Gunalan G, Krishnamurthy V, (Late) Saraswathy A. GC-MS AND HPTLC finger printing of Bauhinia variegata leaves for anticancer. World J Pharm Res. 2014; 3(9): 1313-1336.

5. Gilman EF, Watson DG. Bauhinia variegata 'candida' Forest service. Department of agriculture, University of Florida, U.S.A. PP1-2. 1993.

6. Gupta R, Paarakh PM, Gavani U. Isolation of phyto-constituents from the leaves of Bauhinia variegata. J Pharm Res. 2009; 2(8): 1315-1316.

7. Sharma KR, Kalauni SK, Awale S. Antioxidant, phytotoxic and antimicrobial activities of methanolic extract of Bauhinia variegata bark. Journal of Institute of Science and Technology. 2015; 20(2): 37-42. doi: 10.3126/jist.v20i2.13946

8. Afzal Z, Ullah N, Hussain Z, et al. Phytochemical analysis and antibacterial potential of leaf extract of Bauhinia variegate Linn.: An ethno medicinal plant. Matrix Science Pharma. 2017; 1(2): 17-19.

9. Reddy MVB, Reddy MK, Gunasekar R, Caux C, Bodo B. A flavanone and a dihydrodibenzoxepin from Bauhinia variegate. Phytochemistry. 2003; 64(4): 879-882. doi: 10.1016/S0031-9422(03)00416-3

10. Singh $K L$, Singh $D K$, Vinay KS. Multidimiensional uses of medicinal plant Kachnar (Bauhinia variegate Linn.) Am J Phyto Clini Thera. 2016; 4(2): 58-72.

11. Rajkapoor B, Jayakar B, Murugesh N, Sakthisekaran D. Chemoprevention and cytotoxic effect of Bauhinia variegata against nitroso-diethylamine induced liver tumors and human cancer cell lines. J Ethnopharmacol. 2006; 104(3): 407-409. doi: 10.1016/j.jep.2005.08.074

12. Ramadan MF, Sharanabasappa G, Seetharam YN, Seshagiri M, Moersel JT. Charactrization of fatty acids and bioactive compounds of Bauhinia purpurea Linn, seed oil. Food Chem. 2006; 98(2): 359-365. doi: 10.1016/j. foodchem.2005.06.018 
13. Mali RG, Dhake AS. Evaluation of effects of Bauhinia variegata stem bark extracts against milk-induced eosinophilia in mice. J Adv Pharm Tech Res. 2011; 2(2): 132-134. doi: 10.4103/2231-4040.82949

14. Shaheen M, Borsanyiova M, Mostafa S, Bopegamage S, El-Esnawy N. In vitro and In vivo Evaluation of Bauhinia variegata Extracts to Prevent Coxsackie virus B3 Infection. J Protes Bioinform. 2017; 10: 73-78. doi: 10.4172/jpb. 1000426

15. Nariyal V, Sharma P. Kanchnar (Bauhinia variegata) as a medicinal herb: a systematic review. Int J Adv Res. 2017; 5(9): 587-291. doi: 10.21474/ IJAR01/5364

16. Pandey AK, Vijayalakshmi O, Swati Y, Sonu KS. Phytochemical Evaluation and Radical Scavenging Activity of Bauhinia variegatea. Res J Phytochem. 2011; 5(2): 89-97. doi: 10.3923/rjphyto.2011.89.97

17. Egwaikhide PA, Okeniyi SO, Gimba CE. Screening for antimicrobial activity and phytochemical constituents of some Nigerian Medicinal Plants. Journal of Medicinal Plants Research. 2009; 3(12): 1088-1091.
18. Kulkarni YA, Garud MS. Bauhinia variegata (Caesalpiniaceae) leaf extract: An effective treatment option in type I and type II diabetes. Biomed Pharmacother. 2016; 83: 122-129. doi: 10.1016/j.biopha.2016.06.025

19. Modh KM, Pamar PT, Panigrahi B, Anand IS, Patel CN. Pharmacognostical and Phytochemical Evaluation of Leaves of Bauhinia variegata Linn. Pharmacogn J. 2011; 3(24): 45-49. doi: 10.5530/pj.2011.24.9

20. Arain S, Sherazi STH, Bhanger MI, Mahesar SA, Memon N. Physiochemical characterization of Bauhinia purpurea seed oil and meal for nutritional exploration. Polish J food and nutrition sci. 2010; 60(4): 341-346.

21. Mishra A, Sharma AK, Kumar S, Saxna AK, Pandey AK. Bauhinia variegata Leaf extracts Exhibit Considerable Antibacterial, Antioxidant, and Anticancer Activities. 2013. doi: 10.1155/2013/915436

22. Patil JK, Patel MR, Sayyed HY, et al. Pharmacognostic and phytochemical investigation of Bauhinia variegata (linn.) stem bark. Pharma Science Monitor. 2012; 3(1): 1-12. 